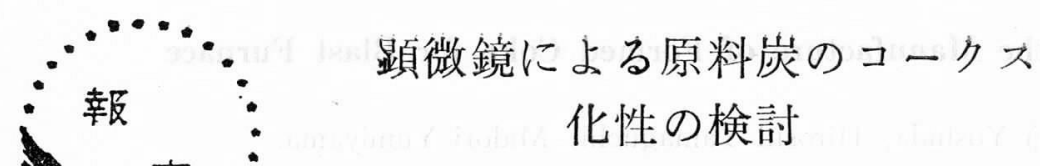

一昭和 45 年 4 月 15 日第 49 回コークス特別会講演一

日本鋼管株式会社 奥山 泰男・宮津隆

石炭技術研究所 杉村 秀彦・熊谷 光照

\section{1. 緒言}

石炭の主成分であるビトリニットの反射率の測定が 可能になつて以来, マセラル 分析と組み合せて, コ 一クス化性を推定する方法が種々検討されている。 Ammosov' ${ }^{1)}$ が Sundgren Test (GOST) 指数を, N. Schapiro2) が Tumbler Test (ASTM) の Stability factor 推定する方式をそれぞれ報告して以来, 数多 くの追試が行なわれた。Brown ${ }^{3)}$ は，米炭とマセラル 組成の異なるオーストラリア炭には Schapiro の方式 は適用できないと報告し，高橋ら4) 日日本炭の場合， コークス強度計算值と実測值間に大きな偏差がみとめ られると述べている。 Benedict ら5) はビトリニット の中で反射率の高い成分 (pseudo-vitrinoid) の不活 性度を考慮した修正方式を提案した。しかしながら Schapiro の方法はその後改良されて, 不活性成分 (イ ナート質) と活性成分の最適比率が修正されている6)。 筆者らは Schapiro の方式*を日本鋼管(株)に入荷 した各種原料炭に適用することを試みるとともに, 前 報8)ではふれなかつた石炭, コークスの諸特性と反射 率およびイナート質の量との関係をも併せ検討した。

\section{2. 実験方法}

2-1 石炭の反射率の測定およびマセラル分析

\section{2-1-1 測定装置}

反射率の測定には，E. Leitz 社製の MikroskopPhotometer M.P.E. 老使用し，これを E. Leitz 社製 の Ortholux-Pol 型偏光顕微鏡に取付けて測定した。 装置の詳細は杉村ら ${ }^{8)}$ の前報告に示すとおりである が，要点を再記するとつぎのようになる。

・光 源……6V, $30 \mathrm{~W}$ タングステン電球

・フィルター $\cdots \cdots \lambda=525 \mathrm{~m} \mu$

·対 物 鏡……単独倍率 $\times 25$ (倍率)

. 接 眼 鏡……単独倍率 $\times 10$

* Consolidation Coal Corp. の数值表 ${ }^{7}$ により再 修正を行なつた。
・測定視野……20 $\mu \dot{\phi}$ 円形

- 基準物質……Zinc blend

マセラル分析には上記の Ortholux-Pol 型偏光顕微 鏡を使用した。諸元も上記と同様である。

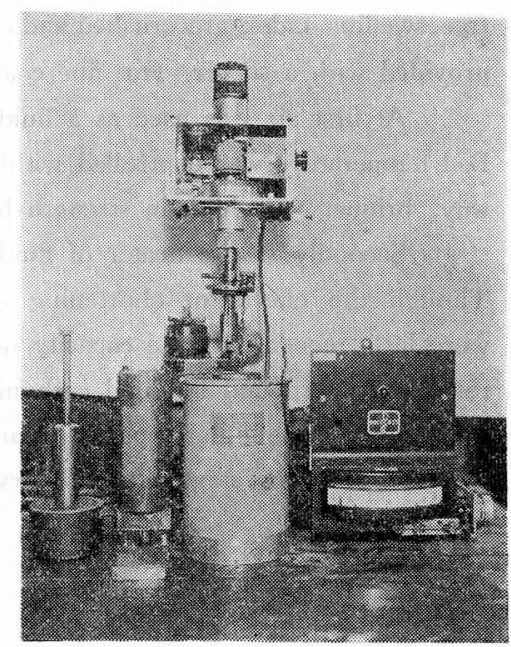

写真 1

\section{2-1-2 測定方法}

杉村ら ${ }^{8)}$ の前報告と同様であるが，その後入手した 下記規格案を参考とした。

1) 試料調製・研磨…...ASTM : D2797-70T

2) 反射率測定……ASTM : D2798-70T

3) マセラル分析……ASTM : 第 5 次案

2-2 石炭の流動性の測定

\section{2-2-1 測定装置}

Fuel Research 社製の constant torque 型ギーセラ ープラストメーター (ASTM : D2639-67T) を使用し た。この装置は, レトルト部, 電気炉部などは従来の 手動式の装置（ASTM : D 1812-66) とほぼ同様であ るが，スターラーの回転を指針でなくマグネチックク ラッチを介してカウンターで直読しらるよらになつて 
いる点が異なる(写真参照)。高流動度炭の場合でも 連続的に測定可能なので精度はよいが，スターラーを 駆動するモーターの回転数が $275 \mathrm{rpm}$ であるために， 27, 500 ddpm でスケールアウトしてしまらのが久点で ある。

2-2-2 測定方法

ASTM : D2639-67T に準じた。測定結果の表示は
つぎの方式によつている。

- 軟化 開始温度 (Initial Softening Temperature) ……タターラーが回り始めて，1ddpmに達したと きの温度

- 最高流動点温度 (Maximum Fluid Temperature) ……最高流動度に達したときの温度

・最高流動度 (Maximum Fluidity)……タターラー

Table 1 Properties of coal and coke tested
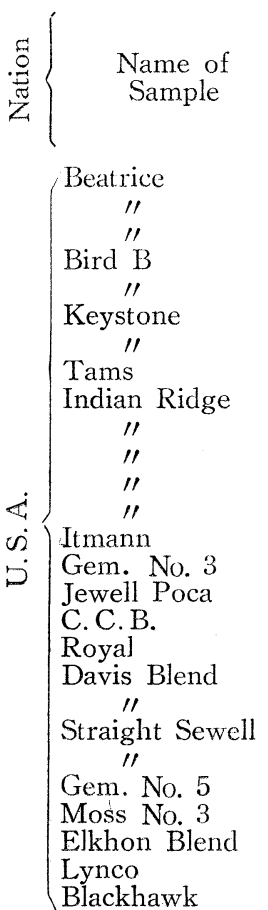

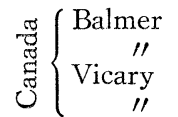

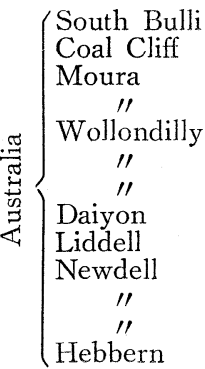

芯 $\left\{\begin{array}{l}\text { Yūbari } \\ \text { Ōyūbari } \\ \text { Kyōei } \\ \text { Heiwa } \\ \text { Miike } \\ \text { Mojiri }\end{array}\right.$

$\begin{cases}\text { Tỏro } & \\ \text { Kuznets } & \text { G-6 } \\ \text { 出 } & \text { KJ-14 }\end{cases}$
Coal

$\begin{array}{ccccc}\text { VM } & \begin{array}{c}\text { Mean Re- } \\ \text { flectance } \\ \text { (daf) }\end{array} & \begin{array}{c}\text { Total } \\ \text { inerts } \\ (\%)\end{array} & \begin{array}{c}\text { Max. } \\ \text { Fluidity } \\ \text { (ddpm) }\end{array} & \begin{array}{c}\text { Total } \\ \text { Dilata- }\end{array} \\ \text { tion (\%) }\end{array}$

\section{8}

\section{5}

18. 6

18. 2

18. 6

17.7

18.1

20.2

21.2

19.6

20. 2

20.0
18.5

19.4

19.7

22.4

27.5

27.8

30.3

28.9

30.0

29.0

30.9

35.5

35.2

36.2

21.6

20.6

24.7

25.1

23.8

26.2

28.8
27.8

27.8

31.7

31.5

30.
39.

39.2
43.3

43.3
42.7

42.5

43.0

44.9

42.1

42.5

43.6

43.5

46.0

44.3

40. 0

42.5

31. 4
1. 86

1. 81

1.75
1.76

1. 80

1.78

1.77

1. 71

1. 61

1.70

1. 70

1. 60
1. 75

1. 66

1. 65

1.50

1. 46

1.43

1.28

1.27

1.17

1.19

1.16

1.16

1.09

1.04

1.02

1.50

1.57

1.45

1.36

1. 43

1. 31

1.10

1. 12

1.02

1. 02

1.05

0.82

0.80

0.76

0.77

0.74

0.76

0.90

0.89

0.82

0.80

0.78

0.79

0.80

0.73

1. 27
21. 1

17.7

13.1

9.2

8.5

18. 7

14.6

17. 1

19.9

21. 1

15.5

11.0

17.8

17.7

12.9

31.8

16.2

19.7

15.7

16.8

17.4

13.3

18.1

12.6

18.3

20.0

17.1

34.4

29.4

30.7

49.9

37.9

31.2
23.7

43. 0

39.3

49.1

24.9

16.9

15.7

21.1

22.5

19. 1

$5.2 \quad 27,500$

$9.427,500$

5.8

4.8

5.5

4.5

4. 8

12.3

36. 9

1,770

4,200

186
1. 40

1. $5 \quad 12.2$

2. 2

3.8

53.5

3.5

10.2

12.3

12.5

2.5

3.8

59

610

320

650

3,200

7,500

10,700

$$
\begin{aligned}
& 2.2 \\
& 2.0
\end{aligned}
$$

3.2

10.5

165.9

168.2

207.0

228.6

100.0

173.9

190.5

53.5

53.5

52.3

23.9

97.7

84.8

4.50

$260 \quad 0$

13.20

12.9

7.3

37.5

7.1
42.6

0

285.4

9.

1.4

Coke

Drum Micro strengh Reactivity

Index
DI $_{15}^{30}$ M.S.I. 28 M.S.I. $65 \quad \frac{\mathrm{CO}}{\mathrm{CO}+\mathrm{CO}_{2}} \times 100$

93.6

93.4

92.4

91.7

92.2

93.3

92.6

92.6

92.2

92.9

91.6

91.6

93.0

91.4

92.5

92.4

93.6
93.4

93.4

93.2

90.2

90.9

91.2

90.1

88.6

89.7

86.4

91.6

91.8

91.8

90.9

89.2

89.4

91.2

90.0

89.2

87.2

86.2

66.4

75.0

69.4

75.3

63.7

65.8

79.0

81.8

69.6

77.9

59. 6

14.736 .0

29.3

$12.6 \quad 41.5$

14.0

14.3 
の回転が最高に達したときの，1 分間当たりのダ イアルの目盛数（ただし水平回転ダイアルは 100 等分してある)

- 固化温度 (Solidification Temperature)……最高 流動点温度を過ぎてコークスが固化し始め, 再び $1 \mathrm{ddpm}$ になつたときの温度

2-3 石炭の Dilatation の測定

吉田製作所製の Audibert-Arnu 型 Dilatometer 使用した。測定方法は Draft ISO Recommendation No. 238 に準じた。

2-4 石炭の乾留

$250 \mathrm{~kg}$ 試験炉を用いた。乾留条件はつぎのとおり。

- 試料粒度…3 $3 \mathrm{~mm}$ 以下 $80 \%, 6 \mathrm{~mm}$ 以上 $0 \%$

- 試料 水 分 $. \cdots . . .10 \%$

・フリュー温度 $\cdots \cdots \cdot 1,100^{\circ} \mathrm{C}$

・乾留時間…12. $12 \mathrm{hr}$

- 置 時 間……4hr

2-5 コークスの性状測定

\section{2-5-1 ドラム強度}

JIS K 2151 （1960）6. により，30 回転指数で表示 した。

\section{2-5-2 マイクロ強度}

H.L. Riley らのの方法に準し，つぎのように表示し た。

M.S. $\mathrm{I}_{28} \cdots \cdots 14 \sim 28$ mesh $の$ 重量\%

M.S. $\mathrm{I}_{65} \cdots \cdots 28 \sim 65 \mathrm{mesh}$ の重量\%

2-5-3 反忘性

JIS K 2151 (1960.) 7. に準ずるが，生成した一酸 化炭素の 流量をオリフィスーマノメーターで 測定する かわりにガスクロマトグラフィーで $\mathrm{CO} \%$ をもとめ, $\mathrm{CO} /\left(\mathrm{CO}+\mathrm{CO}_{2}\right) \%$ を反応性指数 $\left.{ }^{10}\right)$ として表示した。 ガスクロマトグラフィーの測定条件はつぎのとおり。

・カ ラ $\quad$. $\cdots . .$. 活性炭, $4 \mathrm{~mm} \phi \times 75 \mathrm{~cm}$

・カラム 温 度 $\cdots \cdots \cdot 100^{\circ} \mathrm{C}$

・キャリヤーガス……リウム, $30 \mathrm{~m} l / \mathrm{min}$

・検 出 感 度……65 m V

\section{3. 実 験 結 果}

日本鋼管（株）で入手した国内，外原料炭 53 試料お よびその単味コークス（250kg 試験所）について実測 した各種性状を Table 1 に示す。

\section{4. 考 察}

4-1 ギーセラー流動度と反射率の関係

Table 1 に示した各種データのうち, ビトリニット の反射率とギーセラー 最高流動度をプロットすると Fig. 1 のようになる。イナート量が比較的少ない（9
〜25\%) 米国炭，国内炭，豪州弱粘結炭のグループを 結ぶと，図の実線で示したような関係曲線が得られ， 反射率 $0.9 \sim 1.0$ 付近で流動度が最大となり, 反射率が これより高くても低くても流動度は急激に低下寸るこ とがわかる。カナダ炭，豪州中揮発分炭のグループは イナート量が多い(26〜34\%)ために同一反射率の他の グループより流動度が低く，上記の関係曲線より下方 に外れる。Audibert-Arnu Dilatometer の測定值につ いても同様の傾向がみとめられるが，イナート量の影 響はギーセラー流動度の場合よりさらに鋭敏で，カナ ダ炭, 豪州中揮発分炭のグループは軟化時に収縮する のみで膨張を示さない (Fig. 2 参照)。一方高炉の使 用に適する高強度のコークスを得るためには, 配合炭 として適度の石炭化度と流動性を必要とするが，その 範囲は経験上，図の斜線で囲まれた領域でなければな らない。石炭化度がこれ以下になるとコークスとして の固さが不足し, 流動度が高すぎるとクラックが多く なり，低すぎると粒子間の接着が不良となる。したが つて, 配合炭として必要と考えられる 流動度の下限* および平均反射率の下限(約 1.2)を基準として原料炭 を4 群に分類することができよう。すなおち Fig.1の 第 1,4 象限に属する石炭は配合炭の平均石炭化度を 維持するために絶対必要であり, 現在のところ米国 炭, カナダ炭以外にこのグループに属するものはきお めて少ない。第 1,2 象限に属する石炭は平均流動度 を維持するために是非必要であり，とくに国内炭はす ぐれた接着剤としての効果をもつている。将来国内炭 の比率が減少する場合には, このグループの石炭の重 要性はさらに増加するであろら。第 3 象限の石炭は, 石炭化度も流動性も低いので, 配合時の炭素源として の意味しかない。たとえば豪州弱粘炭の使用量を増加 するためには, 配合炭領域の対照の位置にある米国中 揮発分炭を増配合するかあるいは米国低揮発分炭と国 内炭の増配合を必要とすることになる。

以上のような検討方式によれば, 今後開発予定の原 料炭が Fig. 1 のどの位置に属するかによつて開発の方 針をきめることができよう。

4-2 単味コークス強度 $\left(\mathrm{DI}_{15}^{30}\right)$ の推定

4-2-1 Consolidation Coal Corp. の数值表による 推定

㕛射率の測定值とマセラル分析のデータからタンブ ラ一強度を推定するための Consolidation Coal Corp. の数值表 7)（その 1 部を Table 2，3 に示す）を使用

* 現在なだ明確ではないが, 約 $60 \mathrm{ddpm}$ と推定さ れる。 


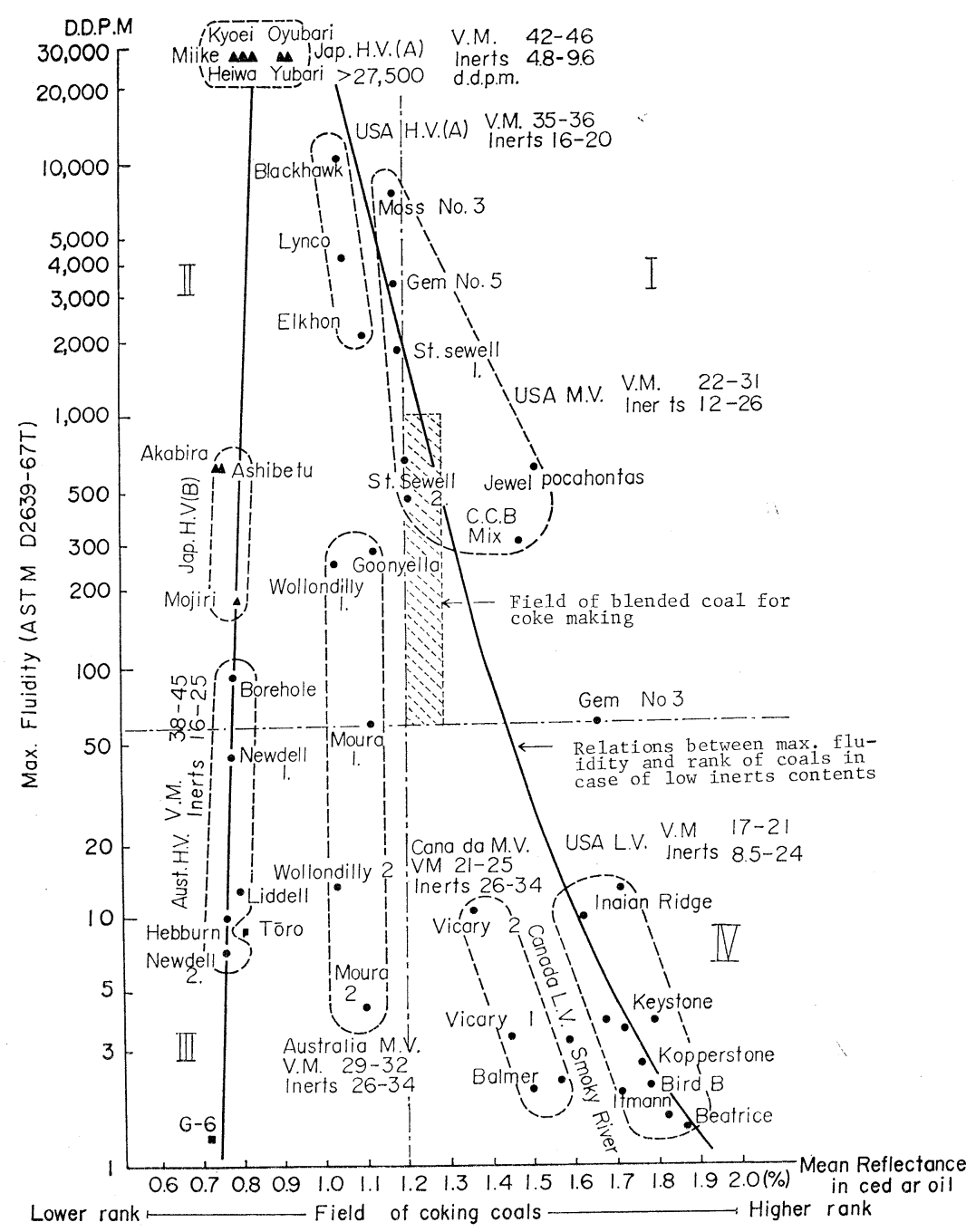

Note: V.M. contents are shown as percent on dry, ash free basis Inert contents are shown as volume percent

Fig. 1 Relation between maximum fluidity and rank of coals

Table 2 Example of strength index for each vitrinoid type

Vitrinoid type

$\begin{array}{lllllllllllllllllll}3 & 4 & 5 & 6 & 7 & 8 & 9 & 10 & 11 & 12 & 13 & 14 & 15 & 16 & 17 & 18 & 19 & 20 & 21\end{array}$

Reflectance in oil (\%)

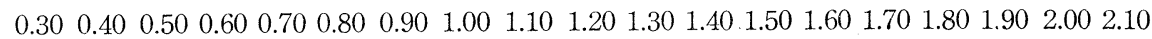

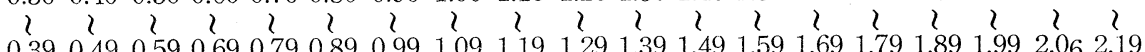
Inerts vol. \%

10.0

2. 152.352 .402 .502 .652 .753 .253 .504 .304 .505 .757 .057 .257 .407 .557 .707 .856 .705 .70

20.0

2.202 .352 .502 .652 .802 .903 .503 .754 .504 .755 .957 .007 .157 .307 .457 .607 .756 .355 .00

30.0

1. 701.952 .102 .302 .402 .853 .653 .854 .454 .705 .806 .857 .007 .107 .307 .407 .605 .854 .05

Table 3 Optimum inerts ratio

$\begin{array}{llllllllllllllllllll}\text { Vitrinoid type } & 3 & 4 & 5 & 6 & 7 & 8 & 9 & 10 & 11 & 12 & 13 & 14 & 15 & 16 & 17 & 18 & 19 & 20 & 21\end{array}$ ratio

$\begin{array}{lllllllllllllllllll}4.4 & 4.0 & 3.7 & 3.3 & 3.0 & 2.8 & 2.5 & 2.5 & 2.9 & 3.5 & 4.5 & 6.0 & 8.0 & 10.9 & 13.6 & 16.0 & 18.2 & 20.7 & 23.0\end{array}$ 


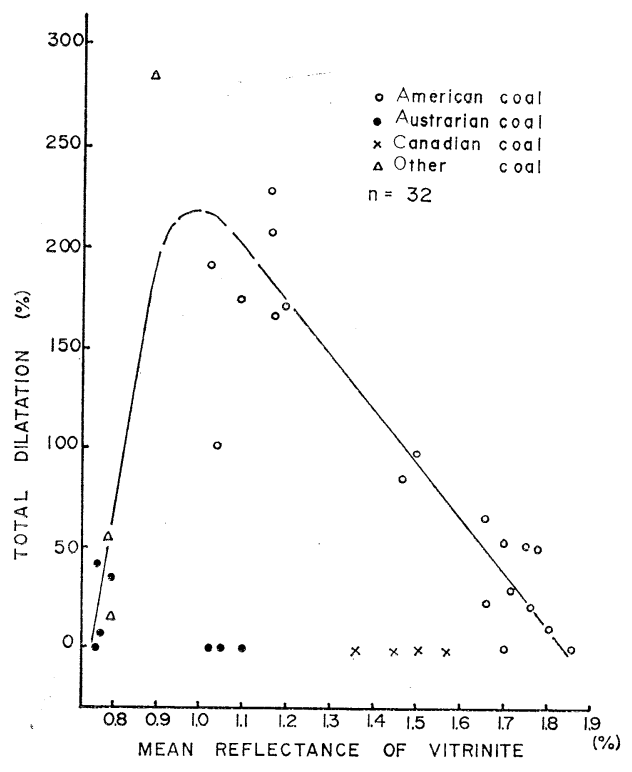

Fig. 2 Relation of reflectance to dilatation

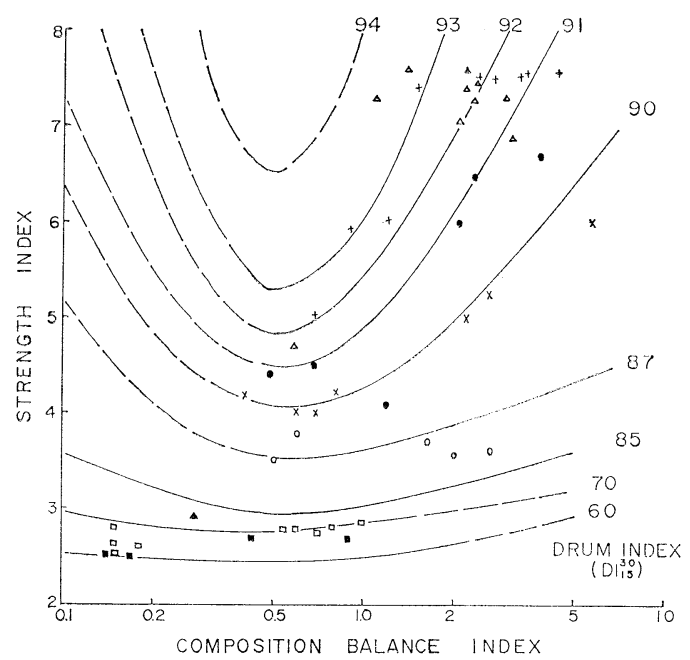

Fig. 3 Relation among Composition Balance Index Strength Index and determined iso $\mathrm{DI}_{15}^{30}$ lines

して，ドラム強度を推定するグラフ（Fig. 3) の作战 を試みた。手順はつぎのとおり。

1) Strength Index をもとめる

各試料炭ごとに実測した反射率およびマヒラル分标 值定つぎの手順によつて処理する。

手順 1） 100 点の反射率測定值を Table 1 によつ て各 Vitrinoid type に分類し, それぞれのビトリニ ット\% $x_{i}$ をもとめる。
手順 2) 备 Vitrinoid type ごとに, 全イナート量 に刘応する係数 $(a, b, \cdots, s)$ を Table 1 からもと め，これに上記％を積算する。

手順 3）次式によつて算出する。

Strength Index $=\frac{a x_{3}+b x_{4}+\cdots+n x_{i}+\cdots+s x_{21}}{\sum x_{i}}$

ただし $x_{i}$ : Vitrinoid type $i$ におけるビトリニッ 下\%

$\sum x_{i}:$ 全ビトリニット\%，これは 100-(イ ナート\%)に等しい。

たとえば，ある試料のイナート量が $20 \%$ であつたとす 狆ば, Table 1 から $a=2.20, b=2.35, \cdots s=5.00$ で あるから, Strength Index はつぎのよらにしてもと められる。

Strength Index $=\frac{2.20 x_{3}+2.35 x_{4}+\cdots+5.00 x_{21}}{100-20}$

2) Composition Balance Index (C. B. I.) をもと める

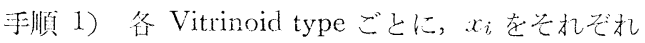
Table 3 のptimum Inerts ratio で割つて集計する。 手順 2) 次式によつて簤出古吕。

$$
\text { C. B. I. }=\frac{100-\sum x_{i}}{x_{3} / 4.4+x_{4} / 4.0+\cdots+x_{21} / 23.0}
$$

3) Strength Index を縦軸に, C.B.I. 胥横軸にとり, 各試料炭ごとの実測ドラム指数 $\left(\mathrm{DI}_{15}^{30}\right)$ の等高線を引 くと Fig. 3 が得られろ。

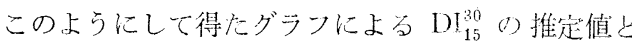
垁測值の関係はFig. 4 に示すこおりで, 高度の相関は 夕とめられる $\left(r=0.92^{* *}\right)$ ものの, $\mathrm{DI}_{15}^{30}<80$ の領域 では推定の精度がわるい。とくに高流動度の（イナー トの少ない）国内炭恃実測值が推定值より高く, 低流

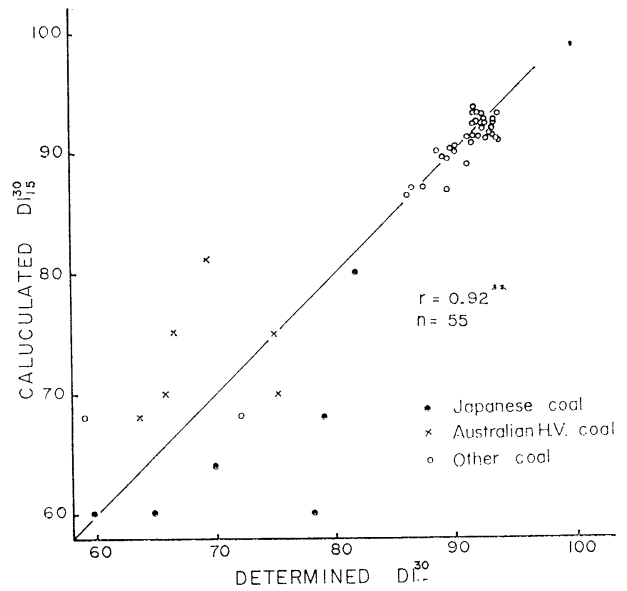

Fig. 4 Estimation of coke strength from petrographic analyses 
動度の (イナートの多い) 豪州高揮発分炭ではこの逆 の傾向を示している。このことは，タンブラー強度推 定用に作られた Table 2，3 の係数が，ドラム強度推 定用に注適当でない一七くに低反射率領域における イナート質の效果を過少評価している—ことを意味 している。いいかえると, タンブラ一強度とドラム強 度に対するイナート量の寄与の程度が異なつているた めに Fig. 4 のような偏差が生じたものと考えられる。

\section{4-2-2 反射率とイナート量のみによる推定}

あらためて，ドラム指数を縦軸に，全イナート量を 横軸にとつて実測值をプロットし，等反射率の点を結 ぶと Fig. 5 のようになる。罒から明らかなように，低 反射率領域では比較的検出力が大きいが，1.1 以上に なると検出力は小さくなり, イナート量の效果も小さ くなつてしまら。このことは後述するよらにドラム試 験法自体の本翼的な 問題に起因するものと考えられ る。

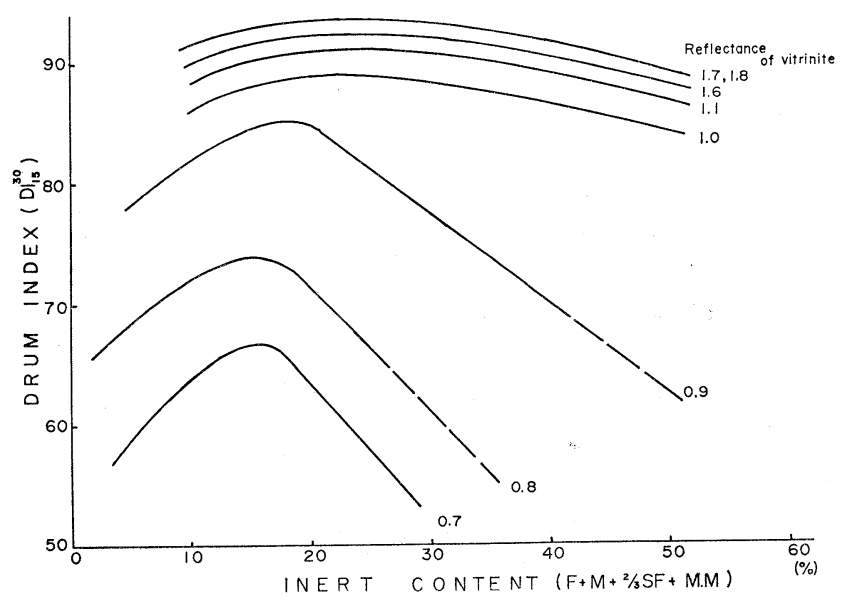

Fig. 5 Relationship between peterographic composition and $\mathrm{DI}_{15}^{30}$

\section{4-3 ドラム強度とタンブラ一強度の差異}

上述したように，石炭の Petrography は原料炭の 価值判定 (とくにコアサンプルの場合など, 試料が少 量しか得られないとき）にはきわめて有力であるが, コークスのドラム強度の予測の精度は, タンブラー強 度予測の場合に比較してあまり良好とはいえない。こ の理由の一つはドラム試験とタンブラー試験の本質的 な差異によるものと考えられる。Fig. 5 に示したドラ 厶強度予測のさいの, 各反射率ごとの最適イナート量 と, Table 3 から算出*したタンブラー強度子測用の 最適イナート量をプロットするとFig. 6 のようにな る。低反射率の領域 $\left(\bar{R}_{0} \leq 1.0\right)$ では両強度指数に対 する最適イナート量の傾向は似ているが絶対值は $10 \%$ 近く差があり， $\bar{R}_{0}>1.0$ になるとさらに著しい差がみ とめられる。この理由は明確でないが，つぎのような 推測をすることはできよら。すなわち $\bar{R}_{0}>1.0$ の領

* Table 3 の最適イナート比の值はイナート 1 に 対する活性成分量を示している。たとえば Vitrinoid type $10\left(\bar{R}_{0}=1.00 \sim 1.09\right)$ ではイナート：活性成分 $=1: 2.5$ であるから石炭全量に対する最適イナ一ト $\%$ は $(1 / 1+2.5) \times 100=28.9 \%$ となる。
域では Fig. 1 に示したように $\bar{R}_{0}$ の増加とともに急激 に流動性が低下（粘着性の低下を意味する）するの で，タンブラー試験のよらに耐摩耗性をよりよく表示 する試験法の場合には粒子間の接着が不良となり，イ

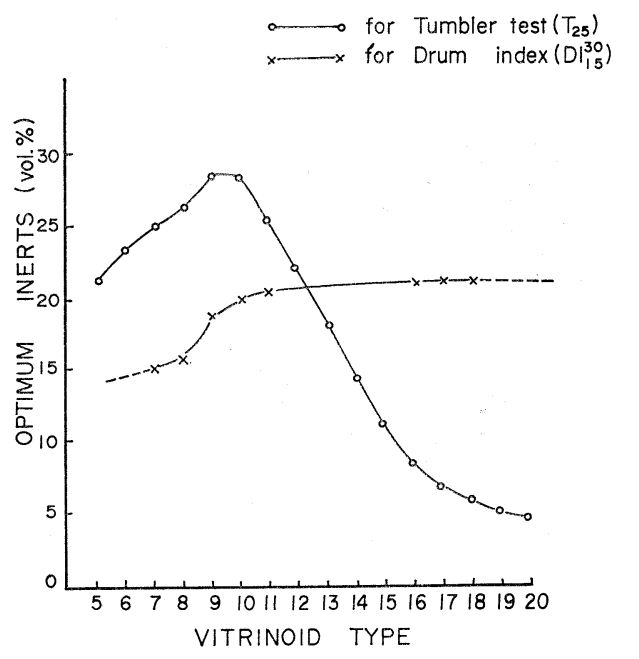

Fig. 6 Chart of the amount of optimum inerts for each vitrinoid type 
ナートの添加許容量が急激に 低下してゆくが， $\mathrm{DI}_{1 \text { J }}^{30}$ の場合にはコークス塊の庵裂がより問題であるために 最適イナート量はあまり変化しないものと考えられ る。

4-4 コークスのマイクロ強度と石炭性状の関係

Table 1 の M.S. I I $_{65}$ のデータは石炭の反射率の值 によつても変化しているが，イナート量の影響をも受 けているようなので，C. B.I. の值で 5 とおりに層別 （タンブラ一強度推定の場合の層別方式と同じ）する と Fig. 7 が得られる。データ数が少ないのであまりは つきりしたことはい充いが，全般的に反射率 1.2 付 近に極大点があり，C. B.I. の值が増大する（イナート の量が增加する）ほど M. S. I 65 の值が低下する傾向が みとめられる。このことから，M. S. I 65 はコークス粒 子間の接着状況を示唆しているといえるかも知机な い。

M.S. I ${ }_{28}$ のデータについては，とくにイナート量の

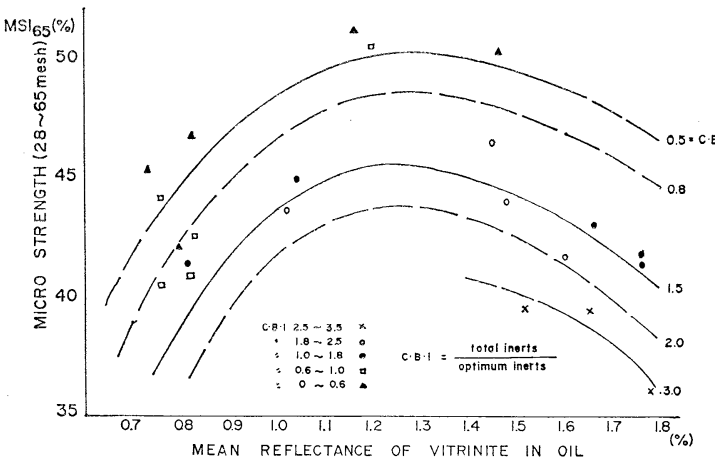

Fig. 7 Relation among the micro strength, the mean reflectance, and the entity composition of coal

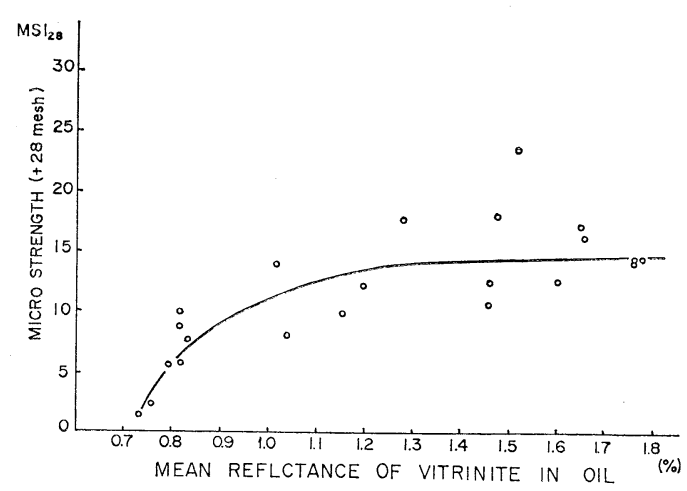

Fig. 8 Relation between the mean reflectance and the micro strength of coke
効果を検出できなかつたので，全データをプールして 反射率との関係をプロットすると Fig. 8 のようにな る。反射率 1.2 までは，かなり急激な M. S. $\mathrm{I}_{28}$ の向上 がみとめられるが，その後は極めてゆるやかな上昇傾 向を示すことがわかる。

4-5 コークスの反応性と石炭性状の関係

コークスの反応性についても，M.S. I 28 と同様イナ 一ト量の効果は検出されなかつたので，全データをプ 一ルして反射率との関係をプロットすると Fig. 9 のよ らになる。かなりばらつきはあるが，傾向としては反 射率 1.2 付近に変曲点があり, Fig. 8 と対照的な曲線 が得られる。コークスの反応性とマイクロ強度間に負 の相関関係があることは従来から知られていた が，Fig. 8，9 の関係も同様な傾向があることを示唆 している。

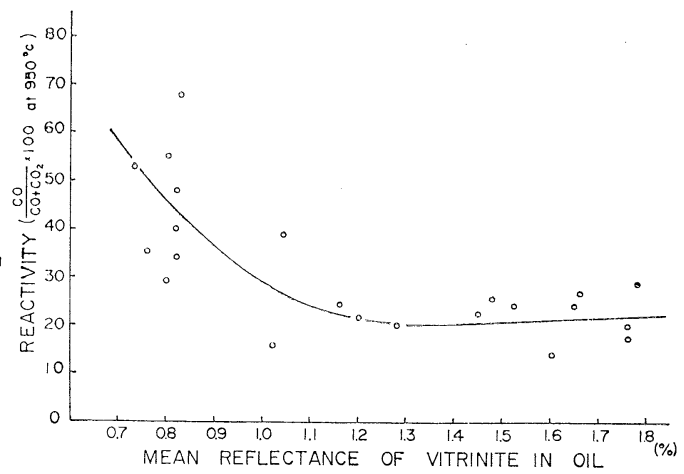

Fig.9 Relationship between the mean reflectance and the reactivity of coke

\section{5. 総 括}

日本の鉄鋼業で使用される各種の原料炭の単味コ一 クスドラム強度の予測に， Schapiro ら 2667) の方式の 適用が可能かぞうかを検討した。53試料についての実 験結果からつぎの事項が推測される。

1）タンブラー強度予測用に作成された数值表》を 使用してドラム強度 $\left(\mathrm{DI}_{15}^{30}\right)$ を予測すると，計算值と 実測值間に高度の相関 $(r=0.92 * *)$ はみとめられる ものの, とくに低炭化度の領域では推定の精度はあま りよくない。この理由はタンブラー試験とドラム試験 の本質的な差異にもとづくものと考㝋られる。

2）ビトリニットの平均反射率とイナート量の実測 值のみから $\mathrm{DI}_{15}^{30}$ を予測する図表を作成すると, 高炭 化度の領域 $\left(\bar{R}_{0} \geq 1.1\right)$ での検出力が低くなる。した がつて， $\mathrm{DI}_{15}^{30}$ 予測の精度を向上するためには今後さ らに精密な実験を行なつて，ドラム強度予測用の独自 
の数值表を作成する必要があろう。

3）石炭の性状 (反射率, イナート量) からコーク スのマイクロ強度, 反応性を予測することは, 精度走 あまり問題にしなければある程度可能である。

4) 反射率とギーセラー流動度によつて原料炭を層 別すると, 両者の関係によつて各国のグループごとの 特長が明確になり, 今後の原料炭新規開発の方向づけ が容易となる。この方式はとくに少量のコアサンプル しか得られないときに有効であろら。

本研究の実施に当たり種々御指導, 御援助を賜わつ た公害資源研究所資源第 1 部木村英雄課長に厚く御礼 申上げます。

\section{文献}

1) I. I. Ammosov, I. V. Eremin, S. I. Sukhenko, L. S. Oshurkova, Koks $i$ Khimiya, No. 12, 9 (1957)

2) N. Schapiro, R. J. Gray, G. R. Euser, "Blast Furnace, Coke Oven and Raw Materials Con- ference" Coal, 89 112 (1961)

3) H. R. Brown, G. H. Taylor, A.C. Cook, Fuel, 42, 43 (1963)

4) 高橋良平, 永井利明, 燃協誌, 48, 928 (1969)

5) L. G. Benedict, R. R. Thompson, R. O. Wenger, Blast Furnace and Steel Plant, No. 3, 217 (1968)

6) N. Schapiro, R. J. Gray, J. Inst. Fuel, 37, 234 (1964)

7) G. R. Friedrich (Consolidation Coal Corp.), 私 信

8）杉村秀彦, 紫波正史, 燃協誌，46, 911 (1967)

9) H. E. Blayden, W. Noble, H. L. Riley, J. Iron Steel Inst., 136, 47 (1937)

10）福山辰夫他, 燃協誌, 47, 607 (1968)

11）久田清明，日本鉄鋼協会第 39 回講演大要録， 47 (1950)

12) 城博, 西徹, 仲摩博至, 同誌, 46, 582 (1967)

\title{
Prediction of the Coking Property of Coal by Microscopic Analyses
}

\author{
by Yasuo Okuyama*, Takashi Miyazu*, Hidehiko Sugimura** \\ and Mitsuteru Kumagai*** \\ (*Nippon Kokan Technical Research Centre, \\ ** Miike Coke Corp, ${ }^{* * *}$ Coal Minning Research Centre)
}

SYNOPSIS:-We attempted the application of Schapiro's method to the prediction of Drum Index of coke made by many kinds of single coal, Informations obtained are as follows;

1) It is possible to predict the $\mathrm{DI}_{15}^{30}$ from the petrographic study of coal, but the precision of the estimation was not so good, though high correlation was found between estimated $\mathrm{DI}_{15}^{30}$ and determined $\mathrm{DI}_{15}^{30}\left(r=0.92^{* *}\right)$.

It suggests that the property presented by Drum Test is differ from that of Tumbler Test. It is necessary, therefore, to perform more detailed studies to obtain the precise prediction system of $\mathrm{DI}_{15}^{30}$.

2) It was not impossible to predict the micro-strength or reactivity of coke from the petrographic study of coal, but the precision of the estimation was also not so good.

3) Various coking coals can be stratified by two parameter-Reflectance of Vitrinites and Gieseler max. fluidity of coal--.

This statifying system is useful to pre-evaluation of coking coals, especially in the case of large quantity of sample can not be obtained. 